\title{
Changing Dynamics of Nepalese Foreign Policy: Patterns and Trends
}

\author{
Bhim Nath Baral
}

\begin{abstract}
After the unification of many tiny states into a single and unified state, the foundation of Nepalese foreign policy was coined by brave, visionary and nationalist king Prithivi Narayan Shah. On the basis of geo-reality, his foreign policy based on non-alignment and neutrality is still relevant. But the subsequent rulers could not maintain their foreign policy images. The trend of changing foreign policy tilt with every change in regime in general and leader in particular created difficulty in foreign policy making. The geo-strategic location of the country on the one hand and continuous political instability in the country on the other always created threat for its survival. The geographical proximity of two Asian powers and their security concern further added more threat upon our independence. All these conditions have played influencing role in the determination of foreign policy choices. Since, Nepal is in advantageous position to benefit from India and China, after a long transition, the newly elected government has almost single choice to act as a balance of local, regional and global interest. So the main objective of this article is to analyze the patterns and trends of Nepalese foreign policy choices. Secondary sources of data are used to achieve the objectives.
\end{abstract}

Keywords: Equidistance, equi-proximity, geo-politics, non-alignment, zone of peace.

\section{Introduction}

Modern world is characterized by interdependency nature. Here the states are the major units of international system who always take part in interaction with the aim to protect their interest. In this age of growing interdependence no nation can remain in 
isolation. So, there are always reasons for interactions among the actors of world community to form international processes. Their interactions are best reflected on the policies adopted by the state towards other states. These policies are generally known as foreign policies which involve regulating and conducting external relations of the state with respect to other in the international scenario. Like internal and domestic politics, a state should pay special attention to the careful formulation and successful execution of foreign policy. It is only through the adoption of sound foreign policy and its effective implementation that a nation's sovereignty is preserved, international dignity is enhanced and the national interest promoted (Thapa, 2014:1). A careful foreign policy enhances a nation's power and prestige in the comity of nations. Achievement in foreign policy also increases the government's credibility in the eyes of public internally as well as externally (Malhotra, 2014:156). So foreign policy has been a very sensitive issue for every policy maker. A nation's foreign policy is formulated on the basis of its position vis-à-vis of the states in the international system. Since it is too hard for a country to remain in isolation in the present day world, it must follow the established pattern of relationship with other and act accordingly. A state must set up the long term and short term objectives clearly to maximize the benefits it can acquire from the established system (Khanal, 2009:98). In such situations, it becomes the primary responsibility of every state to adopt the adequate policy to serve their interest. Though the interest of the state may vary from time to time, it can best be preserved by adopting reasonable foreign policy (Baral, 2072:95). But all the states are not equally found capable in making sound foreign policy in regard to protect and promote their interest. Basically, the small powers like Nepal are unable to make adequate choice in their foreign policy matter. To a large 
extent, Nepal has been struggling hard for its survival in the anarchic international system where there is no super sovereign authority over state to maintain global order and enforce rule (Dahal, 2011:31). It became a compulsive necessity for Nepal to make various choices in foreign policy matter to survive in several challenging modes of history. Through out its history, Nepal has always been cautious when it comes to dealing with both of its immediate neighbours (Republica, 2016:6). Even after the advent of democracy to till date, Nepalese foreign policy choice has remained changing. The tendency to change foreign policy tilt with every change in government has posed difficulty for Nepal to maintain internal cohesion and external adaptation (Dahal, 2011:1). However, Nepal has never remained under the colony of any power country in its history. Our ancestors could preserve the survival of the nation even in the critical days of nation building.

So, the questions automatically arise that what were the major pattern and trend of Nepalese foreign policy? Why different choices were made in foreign policy matter? and how it could be possible for Nepal to preserve the independent identify of the nation? This article aims to achieve the answer of the questions.

\section{Objectives of the Study}

The principal objective of this article is to analyze the changing dynamics of Nepalese foreign policy. Besides this, the specific objectives are to present a brief account of the evolution and development of Nepalese foreign policy and to assess the changing pattern and trends of Nepalese foreign policy.

\section{Methodology}

In spite of its small strength, Nepal was able to maintain its existence during its early stage of nation building. It was possible 
through the adoption of adequate foreign policy. But along with the passage of time, foreign policy making and its execution has become a challenging task. So, this article is mainly related with the changing patterns and trends of Nepalese foreign policy in different modes of history. So, the study is made on descriptive and analytical design. The required data is acquired from secondary sources i.e. books, journals, newspapers, documents and previous research works as well. Library method is used. The nature of data is qualitative.

\section{Concept of Foreign Policy}

International system is composed with different actors. There is continuous interaction among the various actors of global system for the purpose of protecting and promoting their interest. Every actor and their behavior is determined by the fundamental instinct i.e. national interest. The way of dealing or the pattern of interaction of an actor with the other actor is mostly influenced by the core thinking of national interest. By taking this fact into mind, every actor is guided by certain policy. Such policy pursued by a nation while dealing with the other is generally known as foreign policy.

Foreign policy has been defined by several scholars and thinkers on their own accord. It refers to the ways in which the central governments of sovereign states relate to each other and to the global system in order to achieve various goals or objectives (Jaiswal, 2016:2). A foreign policy is generally designed to help, protect and promote country's national interests, security, economic prosperity and independent international image. According to Robert Jackson and Georg Soresen (2013:252) "foreign policy is the management of external relations and activities of nation states, as distinguished from their domestic policies. It involves goals, strategies, measures, methods, 
guidelines, directives understandings, agreement and so on, by which national governments conduct international relations with each other and with international organization and nongovernmental actors". "Foreign policy", as Schleicher views "refers to the actions (including the words) of government officials to influence human behavior beyond the jurisdiction of their own state. In a broader sense, foreign policy includes the objective, plans and actions taken by a state related to its external relationship" (quoted, Malhotra, 2014:156). "Foreign policy", according to Padelfordand Lincoln, "is the key element in the process by which a state translates its broadly conceived goals and interests into concrete courses of action to attain those objectives and preserve its interests "(Quoted, Thapa, 2014:1-2). In the words of Rodee "Foreign policy involves the formulation and implementation of a group of principles which shape the behavior pattern of a state while negotiating with other states to protect or further its vital interests (Quoted in Dahal, 2009:21).

On the whole, it can be said that foreign policy is the instrument to promote national interest. It is the policy pursued by a state incourse of dealing with international community. It is the guideline on the basis of which a state conducts its foreign relations and behaves at international level.

Besides the above definition, foreign policy analysis is based on a broader context of academic knowledge. The concept is determined by several theories. Though theory and policy does not necessarily lead to any one clear policy option, in most cases there will be several different options. Even so, the choice of theory how policy makers view the world is likely to affect the choice of policy (Jackson and Sorensen, 2013:252). However, there are two broad theories with different values emphasizes in the formulation of policy i.e. realism and liberalism. Realism is 
a school of thought that explains international relations in terms of power (Goldstein and Pevehouse, 2008:43). It is based on pessimistic view of human natural. Human are self interested and egoistic. The relations are conflictive and may always lead to war and foreign policy decision making is influenced by the value of national security and state survival (Jackson and Sorensen, 2013:312). Realism is based on a view of the individual as primarily selfish and power seeking. Individuals are organized in states, each of which acts in a unitary ovary in pursuit of its own national interest (Mingst, 2004:66). So, the main concern of foreign policy makers is to manage their insecurity.

The liberal approach, on the other hand, emphasizes the great potential for human progress in modern civil society and the capitalist economy, both of which can flourish in states which guarantee individual liberty. Freedom and democracy are the core values of relations of this school of thought. The liberalists are more optimistic about the prospects for peace and see the rules of international relations as slowly, incrementally evolving through time and potentially becoming more and more peaceful (Goldstein and Pevehouse, 2008:84). This evolution results primarily from the gradual build up of international organization and mutual cooperation and secondarily from changes in norms and public opinion.

The above theories are very relevant in the analysis of the patterns and trends of Nepalese foreign policy. Nepal's geostrategic position sometimes overrides the basic assumptions of the established theories. From realistic point of view, Nepal has been struggling hard for its survival since the very beginning of nation building. Preservation of national independence has long been the most formidable problem of Nepalese foreign 
policy. According to liberalists, "relations between liberal states will be collaborative and cooperative" (Jackson and Soresen, 2013:309). But it could not be realized while making analysis of foreign policy of Nepal and its immediate neighbours. The specific policies pursued by the various governments may have varied from time to time in accordance with changing circumstances, but certain basic considerations have delimited both the style and the content of their responses to external influence and challenge (Rose: 1971:277).

No doubt, a nation formulates its foreign policy keeping in view of its various national interests and objectives. For this, general, internal and external determinants also play varying degree of role due to which foreign policy takes different terms and shape in different countries. The view of policymakers a country's approach towards outside world is likely to affect the choice of policy. Policy of isolation, policy of special relation, policy of equidistance, policy of zone of peace, policy of nonalignment and the policy of equi-proximity have remained the major foreign policy choices of Nepal. The trend and pattern of changing foreign policy is discussed in the following points:

\section{Evolution of Nepal's Foreign Policy}

Nepal, as a landlocked country, is strategically located between two very strong and powerful countries of Asia, China and India. Due to the unique geographical location of the country, the rulers have remained cautious from the very beginning regarding relations with foreigners particularly the two immediate neighbors. This fact is reflected very well in Prithvi Narayan Shah's teaching (Divya Upadesh). It was during the second half of eighteenth century that, the brave, visionary and nationalist king Prithvi Narayan Shah provided not only the basis for modern Nepal's foreign and security policies but has 
also contributed in shaping its worldview (Khanal, 2009:96). He stated that Nepal is yam between two boulders. He further said that great friendship should be maintained with the Chinese emperor. Friendship should also be maintained with the southern seas (The British) (Aryal andet. al., 2011:15). His suggestion was not to engage in an offensive attack, fighting should be done a defensive basis. If it is found difficult to resist in the fight then even means of persuasion, tact and deceit should be employed (Acharya, 2070:13).

\section{A. Independent Foreign Policy}

As Prithvi Narayan Shah was fully aware about geostrategic reality of Nepal and had suggested his followers to adopt independent foreign policy. This spirit can be vividly seen in his 'DibyaUpadesh'. But the succeeding rulers could not maintain independent and non-aligned foreign policy as Nepal involved in wars with Tibet and British India in 1792 and 1814 respectively (Khanal, 2009:100). As a result, Nepal's boundary was more or less fixed. Basically, the Sugauli Treaty (1816) had limited Nepal's external relations and British India remained the only focus of Nepal's external dealings. The crisis in foreign policy and its subsequent consequences could be seen right from the Sugauli Treaty.

\section{B. Policy of Isolation}

British India-centric foreign policy had introduced in Nepal after Sugauli Treaty. Jung Bahadur's rise in power after KotParva on the night of September 14, 1846 established Rana rule and resulted in a major redefinition of Nepal's foreign policy (Lamsal, 2017:4). A practical Politician like Jung Bahadur was also aware of the decline of Chinese power and it was not in a position or willing to challenge the British power in the Himalayan area and he adopted British -centric foreign policy Changing Dynamics... Bhim Nath Baral - 32 - 
(Rose, 1971:106) . The chief aim of the Rana prime ministers, including that of Jung Bahadur, had been to keep up good relation with the United Kingdom. As a result, Nepal in those days looked at the international problems from the British point of view (Khanal, 2000:1). Nepalese foreign policy was given additional emphasis with Jung Bahadur's visit to England as the visit strengthened his view that British rule in India was not going to be easily overthrown and that the confrontation with the British would be something like playing with fire. The ties of relation became more close when Nepal assisted the British ruler to suppress Sipoy Mutiny of 1857 (Thapa: 2016:14). Jung Bahadur's visit to Europe via-Britain, contribution of Nepalese army in world wars in support to Britain also supported to make the relation more close. All these factors kept Nepal in isolation from the rest of the world. It is true that the policy of isolation would eventually also prove to be beneficial to the continuation of Rana regime and to serve the country from British usurpation as well (Sharma, 2006:15). Finally, during Rana days Nepal was thus isolated from the current of world opinion, parochial conservatism, distrust and doubt- all these elements cast their weight on the foreign policy in the past (Khanal, 2000:2).

\section{Policy of Special Relation}

The political change of 1950 brought 104 years old Rana oligarchy into an end. The newly introduced democratic system paved new pattern in foreign policy outlook. However, Nepal's external relations during king Tribhuwan's rule were dominated by India. The two countries were described as having had "special relation" with each other (Muni, 2016:59). This relation was mainly confined with our southern neighbor. Nepal's relation with China was rarely cared. There were various factors that accounted for "Special Relations" between 
Nepal and India. The tie of special relation between Rana ruler and British India was rooted during Rana rule. After British departure from sub-continent, no substantial changes occurred in the situation. Signing of tripartite agreement providing for the British recurrent of the Gurkha soldiers in India, peace and friendship treaty of 1950, extradition treaty with India in 1953 etc. were the major events to have special relation with India (K.C. 2072: 1-22). It was also stated that the peace and friendship treaty was concluded at a time when Nepal feared a Chinese threat, particularly after the Chinese occupation of Tibet (Saran, 2017:153). It was also in practice that Indian ambassaders to Nepal had to attain the cabinet meeting. Govinda Narayan, the home secretary of Utter Pradesh, was deployed as the special secretary of king Tribhuwan (K.C., 2072:14) Besides these, India's role in Anti Rana movement and familiarity of Nepalese freedom fighters with Indian soil were also responsible for the situation. When we talk about special relation, the matter of dependency, special direction and interest came upon the small states (Shahi, 2073:133). All these situations created India's open influence in Nepalese foreign policy.

\section{Non-aligned Foreign Policy}

The devastating Second World War brought sea changes in world politics. The pre war friends started to form their own alliances just after the post war international relations. Nepal also witnessed a new chapter in its foreign policy. An important political development that contributed to the new state of affairs was king Mahendra's coming to power. Two outstanding events took immediately after the accession of king Mahendra to the throne on March 13, 1955. Nepal's admission to the united Nations and the establishment of diplomatic relations with the communist Chinese government (Rose, 1971:208). The year 
1955 was to be the most significant year in Nepal's foreign policy. Nepal's participation in Afro-Asian conference held at Bandung later paved the way for Nepal's non-aligned foreign policy. It was Bandung conference which provided the bases for nonalignment movement in the form of principles of Panchasheel. From that day onwards,non alignment has remained as the basic guideline of Nepal's foreign policy. Non alignment was a historic necessity for Nepal and as well as others which would create opportunities for the peaceful political development of nations and above all, in a non-military dimension, suggest a middle path before rival pressures (Khanal, 2000:425). Further, It was compulsive necessity for Nepal to adopt this policy to survive in critical days of cold war politics and its own geostrategic location as well.

\section{E. Policy of Zone of Peace}

The most important and original strategic policy adopted by Nepal in order to project its changing security was the proposal of Zone of Peace. When king Birendra ascended the throne of Nepal, he introduced new foreign policy decision to declare Nepal as a 'Zone of Peace'. The concept was first mooted in 1973 at the non-aligned summit held at Algiers. It was formally forwarded at the coronation ceremony of king Birendra held in Kathmandu on 25 February 1975 (Sharma 2006:239). The main theme of declaring Nepal as "Zone of Peace" was to maintain neutrality in all possible regional conflicts and also ensure domestic political stability and economic development (Muni, 2016:234-235). The events in the neighbourhood were threatening the security of the nations and world political situation was also in critical mode. India's assertion of its position following its policy tilt to the Soviet Union in 1971, active role in the division of Pakistan and emergence of Bangladesh, annexation of Sikkim, a tiny 
Himalayan state close to Nepal and nuclear test inspired Nepal to innovate a new policy initiative to be declared Nepal as a "Zone of Peace" (Dahal 2011:41). Nepal also faced difficulties during this time due to Khampa incident and other domestic problems (Baral, 2072:97). The proposal was mostly based on the spirit of nonalignment and principles of Panchasheel. So, it received overwhelming support from 116 countries but India has not yet welcomed by thinking that Nepal had certain other objectives (Srivastav, 2016:41).

\section{F. Policy of Equidistance/ Equi-proximity}

Nepal's foreign policy has remained a difficult, serious and sensitive subject owing to its geopolitical and underdevelopment. In course of dealing with foreign policy matters, Nepal's geopolitical and geostrategic location has obligated it to adopt a balance policy with its immediate neighbors. Nepalese foreign policy was under the dominance of India till mid 1950s. Nepal's entry into global environment was opened after its membership in UNO in 1955. The then king Mahendra adopted the policy of maintaining equal relation between India and China. The one sided relation now started balancing with the construction of Araniko Highway despite India's objection (Thapa, 2016:19). Nepal's strong commitment on non-aligned movement and considering the principles of Panchasheelas the bases of Nepalese foreign policy became the steps towards maintaining equidistance foreign policy. Mahendra also shaped Nepalese foreign policy to suit the times by diversifying and establishing diplomatic and commercial relations with different countries of the world.

During the Panchayat Period, Nepal had emphasized the policy of equidistance regarding its relation with the two immediate neighbours. After 1990, the concept of equi-proximity was 
introduced to justify the closeness with Nepalese power centers basically with immediate neighbours. According to Dhruba Kumar as quoted by Dahal (2009:34-35) the term "equiproximity" as "a conception guaranteeing a balanced relationship with both India and China. Sovereign equality remains central to this proposition. In so doing, Nepal should advisedly undertake an effort to review all the previous treaties and discard the ones that had proved unfavourable to the country's national interests. The thrust of the argument conclusively points towards ending the special relationship with India, which restricts Nepal's freedom to maintain a meaningful relation with China. Nowhere has this feeling been reflected more correctly in recent memory than in the case of Chinese arms versus Indian blockade." Compared to the diplomacy of equidistance, Nepal's success in the diplomacy of "equi-proximity" which is a constructive policy based on mutual trust, equal benefit and cooperation.

The question of "balanced relation" is equally vital in Nepalese foreign policy determination. Many Indian foreign policy makers stressed India's special relationship with Nepal and became and highly objectionable of Nepal's policy of balanced relationship as both are closed in terms of cultural, economic, geographic and social conditions (Singh and Shah, 2016:56). The issue of balanced relation always remained a subject of debate. Formulation of foreign policy on the party line has created more fundamental issues. The leftist government is often blamed for following 'pro-Chinese policy' whereas the rightist or centrist government follow a 'pro-India policy'. But it is the geo-political reality for any government of Nepal not to be either 'pro-Chinese' or 'pro-Indian'. So, equi-proximity should be maintained in dealing with our immediate neighbours. However, Nepal has remained neutral in the conflict between India and China.Related to Doklam issue, in June 2017, Nepal had made 
it clear that it will stay neutral in the latest India China standoff, and it wants this issue to be resolved peacefully. Nepal had also remained neutral in Indo-China war of 1962.

\section{G. Nepal and Trilateral Cooperation}

Although, globalization has created inter-dependency and countries are unable to exist and develop in isolation, still the politics of power and hegemony discourages the interest of small powers on an equal footing. Nepal has been experiencing the direct impact of enmity, cooperation and competition of India and china. Their relation is full of enmity, cooperative and competitive from the point of view of border, trade and strategic issues (khanal,2073:286). The recent case of LipuLekh has raised the questions regarding our position. While reaching bilateral understanding during the Indian Prime minister Narendra Modi's visit to Beijing in May 2015, the Chinese President $\mathrm{Xi}$ Jinping and Modi were reported to have agreed to use this corridor for their interest (Baral;2016:13). So, the significant question then is: can there be a balanced trilateral relationship between the three countries? However, the issue of trilateralism is a compulsive necessity for all Nepal, China and India because of political, strategic and geo-realities.

In the recent years, both the leaders of India and China have focused on development and economic prosperity. They have made massive progress in road, railway and maritime connectivity too. $\mathrm{Xi}$ Jinping's ambitious project of OBOR (One Belt One Road) has the aim to be connected with about 60 countries of Asia, Africa and Europe. President's vision of creating a 'community of common destiny' through 'Go West' and 'Peripheral Strategy'(Subedi, 2016:41)have extended a kind of significant advancement of India in the field of Science and technology and its 'Neighbourhood First' Policy can be fruitful 
for our prosperity. If these policies are honestly enforced, the concept of trilateralism can be materialized.

But it does not mean that our immediate neighbours will put aside their security concern. China is always cautious about whether Nepali land might be used for anti-China element. China is more concerned about Tibet issue when it comes to dealing with Nepal. The border dispute, the Tibetan refugee issue and china's strategic relation with Pakistan continue to be irritants in ChinaIndia relations (Baral,2016:11-25). India is equally worried about growing Chinese influence in Nepalese Politics. India is not happy with Chinese investment in infrastructure and energy in Nepal. Besides these, the open border borne problems like circulation of fake currency, increasement in criminal activities, rising terrorists attack, illegal trade, drug and human trafficking, etc always create tension between two countries. Growing antiIndian Sentiment in Nepal has also created more problems. However, Nepal is committed to ensure its neighbours about their security concern by not allowing the Nepalese land for the activities against them.

\section{H. Constitutional Provision}

Constitution is the major guiding document of the overall affairs of the nation. As the supreme law, the Constitution of Nepal 2072 has made clear provision about Nepalese foreign Policy. The latest constitution has not made any substantial changes regarding foreign policy. However, part four of the constitution has made the provision of directive principles, policies and obligations of the state. It is mentioned that the state shall direct its international relations towards enhancing the dignity of the nation in the world community by maintaining international relations on the basis of sovereign equality, while safeguarding the freedom, sovereignty, territorial integrity and independence 
and national interest of Nepal(article 50(4). Likewise, under the topics 'Policies of States' the state has the aim to conduct an independent foreign policy based on the Charter of the United Nations, non-alignment, Principles of Panchasheel, International law and the norms of the world peace taking into consideration of the interest of the nation. While remaining active in safeguarding the sovereignty territorial integrity, independence and national interest of Nepal (article 51(m(1)). The additional provision made in the constitution is that the government will pursue the policy to review treaties concluded in the past and make treaties, agreements based on equality and mutual interest (article 51(m)2). There have been several changes in guidelines of foreign policy are almost same. With the change in situation it is necessary to rethink about Nepalese foreign policy. Basically it is the demand of the general public and political parties of Nepal to rethink about the relation with the southern neighbour.

\section{Formation of Eminent Persons Group (EPG)}

Nepal and India are so well bounded by various cultural, religion, social, economic and geographical ties. But the relation has remained paradoxical as commented by India diplomat, Shyam Saran (2017:149). Basically, Anti India sentiment is growing in Nepal especially after Indian blockade of 2015. It is a subject of debate regarding the treaties signed between the two countries in different times. By realizing the fact, a joint mechanism with a group of foreign policy expert called Eminent Persons Group (EPG) has formed. The mandate that was given to EPG following the meeting between (then) Prime Minister K.P. Oli and Prime Minister Narendra Modi on 20 February, 2016 included taking a serious look at a possible review of Friendship treaty which was concluded decades ago. The EPG has formed to look into the totality of Nepal- India relation from independent,. non- 
governmental perspective and suggest measures to further expand and consolidate the close and multifaceted relations between the two governments. The EPG group from Nepali side is headed by Bhekh Bahadur Thapa, former foreign minister of Nepal with Nilambar Acharya, Dr Rajan Bhattarai and Suryanath Upadhaya as the members. Likewise, Bhagat Singh Koshiyari, Leader of Indian ruling party, is heading Indian side with Dr. Mahendra P.Lama, Prof B. C.Upreti and Jayanta Prasad as the members(the Kathmandu Post, 6 July, 2016;1). The eight members group have been entrusted with the responsibility of putting together a mutually agreed document within two years to suggest ways to strengthen bilateral ties in view of evolving regional dynamics and world order. The EPG has the main aim to revise the bilateral agreements and arrangements. Generally, it has the mandate to take into five broad areas of Nepal-India ties i.e. political relation, government to government ties, development cooperation, economic exchanges and social and cultural relationship. Hope that its recommendations will be fruitful in strengthening the relation between these two closed neighbours.

\section{J. Nepal and the World Community}

Nepal's entry into international community formally opened only after its membership of the UNO in 1955. Further, Nepal also became the temporary member of Security Council of the UNO twice (1969-1970 and 1988-1989). Nepal is one of the founder members of NAM which formally initiated from 1961. Nepal's contribution in the establishment of SAARC in 1985 and establishment of SAARC Secretariat in Kathmandu has enhanced its prestige. Nepal's involvement in BIMSTEC (Bay of Bengal Initiatives for Multi-sectoral Technical and Economic cooperation) in 31 July, 2004 has widened its image in the world 
community. Currently, Nepal is chairing SAARC and BIMSIEC but Nepal's failure to organize their summits has raised many questions in its ability to regulate foreign policy.

\section{Conclusion}

From the very beginning of the formulation of Nepal's foreign policy the founding ruler Prithivi Narayan Shah had realized the geographical reality and recommended very cautious relations with them. After his demise, neither his successors could fully realized the actual situation nor could maintain national unity. In such situation, Nepalese foreign policy could not catch the fundamental shape. It passed through different patterns and the situations drastically brought substantial changes in foreign policy outlook. Neutral and non-aligned foreign policy, policy of isolation, era of special relation, equidistance policy, policy of zone of peace, non-aligned foreign policy, etc. were chosen in different periods of history. Whoever became the ruler, their main intention of making certain foreign policy was to sustain their regime. Even after the restoration of democracy, foreign policy choice could not go beyond party line. Whenever the ruler failed to manage internal affairs and tried to divert internal political conflict to the external affairs, they have invited trouble. The situation even put serious limitations to the country's pursuit of independent foreign policy.

Finally, after a long struggle with many ups and downs, political transition has somehow ended. The parties and general public have single fold demand for economic prosperity. In such condition, our immediate neighbours can be the decisive factors to achieve economic soundness through the transfer of aid/ investment, technology and market as well. It needs careful balance of own structure by giving proper attention in the management of their interest. We should make Nepal as a bridge 
between two emerging economies. We further need to maintain triangular relationship by action as a bridge between the two rising powers and play an active role in the establishment of trilateral cooperative ventures. The relation with one neighbour can't be taken at the cost of another. Our foreign policy should address the fragile image as one of the poorest and conflict prone state and its gradual erosion of international acceptability. Realizing all these factors so essential for the existence of Nepal, a comprehensive consensus should be built on the foundation of foreign policy through internal solidarity and it should be taken into operation.

\section{References}

Acharya, Jayraj (2070 B.S.). Nepalko Rastriyata Ra Pararastra Niti,

Vichar Prabaha, Versa 2, Anka 2, Pokhara: Prajatantrik Vichar Samaj, Pokhara.

Aryal Dornath, Ram Prasad Subedi and Surendra Thapa (2011).

Diplomatic Dealings. (fourth edition): Kathmandu: Apex Educational Academy.

Baral, Bhimnath (2072 B.S.). Foreign Policy of Nepal: Bases and Challenges in Legal Eye Kaski, Nepal Democratic Lawyers Association, District Committee, Kaski.

Dahal, Devraj (2011). The Art of Survival: Policy Choices for Nepal in Dhaulagiri Journal of Sociology and Anthropology. Vol. 5. Dahal Ramkumar (2009). Challenges in the formulation of foreign Policy for Nepal in Nepalese Foreign Policy at the crossroads.

Edited by Sushil Raj Pandey and Pushpa Adhikari, Kathmandu: Sangam Institute.

Dibya Upadesh (2054 B.S.). His Majesty the Government, Ministry of Youth, Spot and Culture. Department of Archaeology.

Goldstein, Joshua S. And Jon C. Pevehouse (2009). International Relations (Eight Edition). Dorling Kindersley India Pvt. Ltd, 
PEARSON.

Hamal, Yagya Bahadur (2014). Ecology of Nepal's Foreign Policy. Kathmandu: Nepal Centre for Development and Policy Studies Pvt. Ltd. (CEDEP) Nepal.

Jackson, Robert and Georg Sorensen (2013). Introduction to International Relations: Theories and Approaches. Fifth Edition: Oxford University Press.

Jaiswal, Pramod (2016). Nepal's Foreign Policy and strategic Significance in Nepal's Foreign Policy and Her Neighbours. Edited by Pramod Jaiswal and Geeta Kochhar, Delhi: Smt Neelam Batra, GB Books Publishers and Distributers.

K.C. Surendra (2072 B.S.). Nepalko Bharat Niti Tatha SandhiSamjhautaharu in Nepal-Bharat Ra Chin Sandhi Samikshyatmak Vivechana. Kathmandu: Madhuvan Prakashan.

Kantipur National Daily, 8 August, 2017.

Khanal, Gopal (2073 B.S.). Bhurajniti, Kathmandu: Phoenix Books. Khanal, Rabindra (2009). Donor Community and Nepal's Foreign Policy in Nepalese Foreign Policy at the Crossroads. Edited by Sushil Raj Pandey and Pushpa Adhikari, Kathmandu: Sangam Institute.

Khanal, Y.N. (2000). Nepal's non Isolationist Foreign Policy. Kathmandu: Satyal Publications.

Lamsal, Yubanath (2017). Jung Bahadur's Foreign Policy in The Rising Nepal, March 7, 2017.

Malhotra, Vinay Kumar (2014). International Relations (Fourth Revised and Enlarged Edition).New Delhi: Anmol Publications Pvt. Ltd.

Morganthau, Hans J. (1997). Politics Among Nations: The struggle for Power and Peace (Sixth Edition). New Delhi: Kalyani Publishers. Muni, S. D. (2016). Foreign Policy of Nepal. New Delhi: Adroit Publishers.

Palmer, Norman D. and Perkins Howard C. (2015). International 
Relations (Third Revised Edition). New Delhi: AITBS Publishers, India.

Republica, Nov. 2016, Vol. VII, No. 163 P. 6 (Editorial).

Rose, Leo E.(1971). Nepal Strategy for survival. London: University of California Press.

Saran, Shyam (2017). How India Sees the World. New Delhi: Juggernaut Books.

Shahi, Yogendra (2073 B.S.). Nepal Bharat Sambandha: VisheshHoina, Ashal Sambandha Ko Awashyakata in Nepal Bharat Sambandha: Bigat Bartamanra Bhavishya. Edited by Bijaya Kumar Poudel. Kathmandu, Milestone Prakashan Tatha Prasharan Ltd.

Sharma,Jagadish (2006). Nepal: Struggle for Existence. Kathmandu: Comm INC ICT Private Ltd.

Singh, Bawa and Shah, Shabaz Hussain (2016). Nepal's Equidistance policyTowards India and China: Exploring the Shifting Paradigm in the Post-Monarchial Era in Nepal's Foreign Policy and Her Neighbours. Edited by Pramod Jaiswal and Geeta Kochhar, Delhi: Smt Neelam Batra, GB Books Publishers and Distributors. Srivastav, Vivek Kumar (2016). Nepal's Foreign Policy in Quest of Identity in Nepal's Foreign Policy and Her Neighbours. Edited by Pramod Jaiswal and Geeta Kochhar, Delhi: Smt Neelam Batra, GB Books Publishers and Distributors.

The Constitution of Nepal (2072 B.S.). Government of Nepal, Ministry of Law, Justice, Constituent Assembly and Parliamentary Affairs, Law Book Management Committee.

The Kathmandu Post, 6 July, 2016. 